\title{
Trophic overlap of lionfish (Pterois volitans) and two native predators (Lutjanus apodus and Cephalopholis cruentata) in the western Caribbean
}

\author{
Brenda Iveth Murillo-Pérez $z^{1}$, Juan Jacobo Schmitter-Soto ${ }^{1 *(0)}$, Dorka Cobián-Rojas ${ }^{2}$ \& \\ Roberto Luis Herrera-Pavón ${ }^{1}$ \\ ${ }^{1}$ El Colegio de la Frontera Sur, Departamento de Sistemática y Ecología Acuática, A.P. 424, 77000 Chetumal, \\ Quintana Roo, Mexico. \\ ${ }^{2}$ Parque Nacional Guanahacabibes, Centro de Investigaciones y Servicios Ambientales, La \\ Bajada, Pinar del Río, Cuba. \\ *Corresponding author: Juan Jacobo Schmitter-Soto, e-mail: jschmitt@ecosur.mx
}

MURILLO-PÉREZ, B.I., SCHMITTER-SOTO, J.J., COBIÁN-ROJAS, D., HERRERA-PAVÓN, R.L. Trophic overlap of lionfish (Pterois volitans) and two native predators (Lutjanus apodus and Cephalopholis cruentata) in the western Caribbean. Biota Neotropica 21(1): e20190909. https://doi.org/10.1590/1676-0611-BN-2019-0909

\begin{abstract}
Impact of invasive species on native biota may be due to predation, competition for space or food, or indirect effects. Lionfish (Pterois volitans), invasive in the western Atlantic, is a voracious generalist predator, so it is expected to have a significant trophic overlap with native fishes of comparable size and habits. The goal of this study was to determine the diets of potential competitors of the lionfish, in particular a grouper, Cephalopholis cruentata (Graysby), and a snapper, Lutjanus apodus (Schoolmaster), and to compare them to the diet of lionfish in Xcalak, southern Mexican Caribbean. Stomach contents were analyzed and electivity and diet overlap were estimated. The trophic overlap between the lionfish and the two putative competitors, especially the grouper, was high, including prey that was consumed by the predators in higher proportion than the relative abundance of the prey in the environment, and probably at the same time of day. Lionfish and grouper shared as important diet items Stegastes sp., Halichoeres sp., Brachyura, and Palaemonidae, and most full stomachs were found during the early morning. The hypothesis of competition between them for particular prey is supported, so we advise to continue the culling programs of lionfish and also to monitor the abundance of the possible native competitors.
\end{abstract}

Keywords: Feeding habits; native predators; invasive species; competition; Mexico.

\section{Traslape trófico del pez león (Pterois volitans) y dos depredadores nativos (Lutjanus apodus y Cephalopholis cruentata) en el Caribe occidental}

\footnotetext{
Resumo: El impacto de las especies invasoras sobre la biota nativa puede deberse a depredación, competencia por espacio o alimento, o efectos indirectos. El pez león (Pterois volitans), invasor en el Atlántico occidental, es un voraz depredador generalista, de modo que se espera que tenga un notable sobrelape trófico con peces nativos de tamaño y hábitos comparables. El objetivo de este estudio fue determinar las dietas de competidores potenciales del pez león, en particular un mero, Cephalopholis cruentata (payaso), y un pargo, Lutjanus apodus (canchix), y compararlas con la dieta del pez león en Xcalak, sur del Caribe mexicano. Se analizaron los contenidos estomacales y se estimó la selectividad y el traslape de dietas. El traslape trófico entre el pez león y los dos posibles competidores, sobre todo el mero, fue amplio, incluidas presas consumidas por los depredadores en proporción mayor a la abundancia relativa de éstas en el ambiente, y probablemente a la misma hora del día. El león y el mero compartieron como presas importantes Stegastes sp., Halichoeres sp., Brachyura, y Palaemonidae, y la mayoría de los estómagos llenos se encontraron en horas tempranas de la mañana. Se apoya entonces la hipótesis de competencia entre ellos por presas específicas, de modo que recomendamos continuar el programa de extracción de pez león y también el monitoreo de la abundancia de los posibles competidores nativos.
}

Palavras-chave: Hábitos alimenticios; depredadores nativos; especies invasoras; competencia; México. 


\section{Introduction}

Invasive species have the potential to alter the structure and functioning of communities and ecosystems, displacing native species by predation or competition for habitat or food (McCleery 2011; Ruttenberg et al. 2012). The competitive advantages of invaders over natives may be due to the absence of predators and other natural limits in the invaded areas (Weis 2011; Layman \& Allgeier 2012; Paolucci et al. 2013; Raymond et al. 2015). Introduced exotic species may induce trophic cascades (Muñoz et al. 2011; Lönnstedt \& McCormick 2013).

The reduction of available prey induced by the invasive predator can also have an impact on a native predator, and the damage may be further compounded by fishing pressure on the native predator (Albins, 2013; Leung et al., 2015). In addition, the fact that lionfish can both prey on and compete with some native species makes the impact more complex, even stronger, and harder to model and predict (Mills et al. 2004): White et al. (2006) found no clear patterns in the literature that they reviewed about indirect effects of invasive species.

Lionfishes (Pterois volitans and P. miles) are scorpaenids native to Indo-Pacific coral reefs, escaped from the aquarium trade and presently invading the western Atlantic (Semmens et al. 2004). In the western Caribbean, P. miles is known from very few records (Guzmán-Méndez et al. 2017), but lionfish has become abundant and widespread from subtropical USA to Brazil (Ferreira et al. 2015). They are generalist predators that consume a great diversity and abundance of mostly demersal fishes (Cobián-Rojas, Schmitter-Soto, Aguilar Betancourt, et al. 2018), in a variety of habitats (Jud et al. 2014).

Following Albins' (2013) experience with lionfish and Coney, Cephalopholis fulva, our hypothesis is that lionfish should overlap broadly in diet with native predators of comparable size, e.g. groupers and snappers. Most groupers in the western Caribbean are larger than adult lionfish, except the two species of Cephalopholis, C. fulva and C. cruentata, which often are also the most abundant ichthyobenthophagous fishes in the reef (Loreto-Viruel et al. 2003). The former species used to be more common in past decades, dominance shifting recently towards the latter (Schmitter-Soto et al. 2017). As for snappers, many species fall within the size range of the lionfish, the most abundant ones being L. apodus in the reef and L. griseus in mangroves; most individuals found in the reef lagoon tend to be large juveniles or young adults, with larger specimens dwelling deeper in the front reef and younger fish taking refuge among mangrove roots (Nagelkerken 2007).

Stomach contents analysis is the method of choice for identifying specific prey items in diets; Cortés (1997) has advised that data based on volume, based on number of individuals and number of stomachs can be combined in an index of relative importance (e.g. Pinkas et al. 1971). The list of prey species can be greatly expanded if genetic barcoding methods are applied (Valdez-Moreno et al. 2012). On the other hand, a different approach, stable isotope analysis, although losing in taxonomic information, can detect origin signatures of the carbon in fish tissue, thereby determining habitat changes e.g. from mangrove to reef, as well as estimating the trophic level via the isotopes of nitrogen, and combining these to depict trophic niches (Cocheret de la Morinière et al. 2003).The aim of this work is therefore to compare the diets of two potential competitors of lionfish for food resources, grouper $C$. cruentata (Serranidae) and snapper Lutjanus apodus (Lutjanidae), in Xcalak, Mexican Caribbean.

\section{Materials and methods}

\section{Study area}

Field work was carried out in the reef lagoon and the shallower front reef of Xcalak, Mexican Caribbean (Figure 1). The locality, a marine protected area, is part of the Mesoamerican Barrier Reef System, which in its northern part has a well-developed fringing reef. At Xcalak, the reef barrier is punctuated by a few channels, locally termed "quebrados". The reef lagoon is about $1000 \mathrm{~m}$ wide and on average $3 \mathrm{~m}$ deep, with seagrasses and coral patches, as well as sand flats and isolated gorgonians (Ruiz-Zárate et al. 2003).

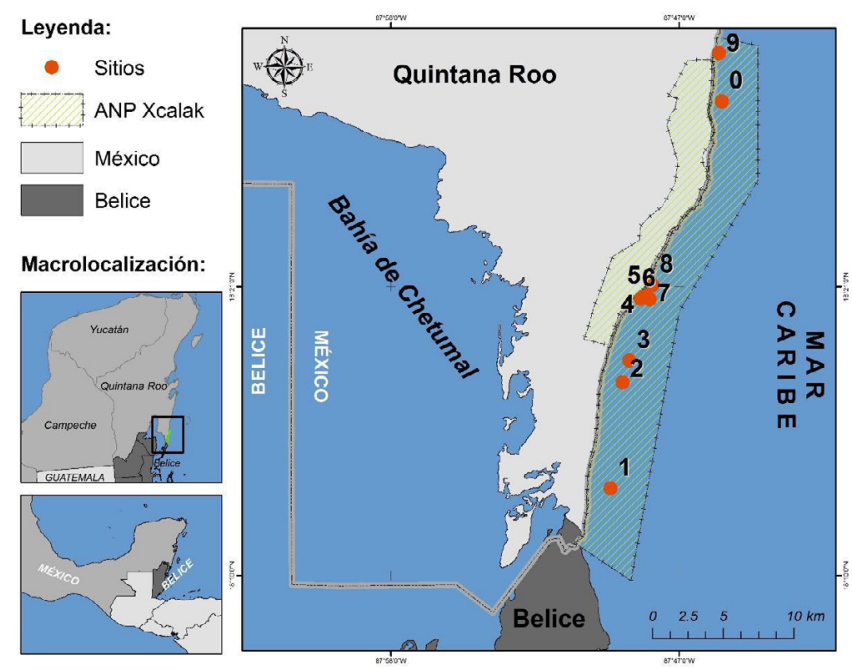

Figure 1. Collection localities (numbered) for Cephalopholis cruentata, Lutjanus apodus, and Pterois volitans, in Xcalak, Mexican Caribbean.

The region has a dry season, usually from February to April, followed by rains in May to September, and a cold-fronts season in October-January (Espinoza-Ávalos et al. 2009). Surface water temperature is high, always above $26^{\circ} \mathrm{C}$, on average $29^{\circ} \mathrm{C}$. Tides are semidiurnal and moderate (a variation of just $20-50 \mathrm{~cm}$ ), but they induce outward and inward currents through the above mentioned "quebrados" (Hernández-Arana et al. 2009). The coastal current usually flows north, although there can be local eddies and countercurrents. Hurricanes occur from June to October, and they can strongly affect the structure of the reef (Jordán-Dahlgren \& Rodríguez-Martínez 1998).

\section{Field and laboratory work}

We sampled in September and October 2014, and March and April 2015 , thus representing both the rainy and dry seasons of the region. We actively searched for lionfish, the grouper, and the snapper in the reef lagoon and the shallow front reef of Xcalak, in coral patches and over algae, sand, and seagrass, at depths from 2 to $10 \mathrm{~m}$; we omitted mangrove, where juveniles of the three species are predominant, and deeper reaches of the reef, where larger adults of the three can be found. We used a variety of fishing gear, including cast nets and hookand-line, but harpoon where snorkeling was most effective. We also acquired specimens of grouper and snapper from local fishermen, and most individuals of lionfish were donated to us by the lionfish control program of the marine park. Given our choice of sampling habitat, most snapper were juveniles (fork length [FL] at first maturity, $25 \mathrm{~cm}$ : Froese 
\& Pauly 2020), whereas most grouper and lionfish were adults (FL at first maturity, $16 \mathrm{~cm}$ and $11 \mathrm{~cm}$, respectively: Froese \& Pauly 2020). Each sampling expedition lasted 4-5 days, and every sampling event took about 2 hours, during daylight (8:00-18:00 h).

The fish were weighed wet in the field with a scale (to the nearest $0.1 \mathrm{~g}$ ) and their total length (TL) measured with an ichthyometer (to the nearest $1 \mathrm{~mm}$ ). Then the stomach was extracted, from the esophagus to the beginning of the intestine (McCleery 2011), and placed in jars with $96 \%$ ethanol, which were kept in ice.

In the laboratory, the stomachs were flushed with water and the contents emptied in a petri dish, where they were classified by recognizable items under a binocular microscope (ca. 10X). The prey were identified using appropriate keys and guides, and the number of individuals counted when possible. Also, the volume of every item, from every stomach, was measured by displacement of water in a graduated cylinder (to the nearest $1 \mathrm{ml}$ ).

\section{Data analysis}

The percentage of empty stomachs for each species was graphically examined to establish whether foraging activity fluctuated by time of day. To do this, the number of collected specimens was controlled by the number of hours and fishers at every time of day (i.e. two-hour intervals, from $8-10 \mathrm{~h}$ to $16-18 \mathrm{~h}$ ).

Prey accumulation curves were fitted as a function of the number of stomachs, using the Clench model with 100 aleatorizations, a sigmoid curve that incorporates a "learning window" at the start and predicts the "true" richness asymptotically (Jiménez-Valverde \& Hortal 2003). For every diet item, three variables were calculated: frequency of occurrence as the percentage of stomachs with the item $(F)$, percent volume $(V)$, and percent abundance, i.e., number of individuals $(N)$. The three variables were examined separately and also combined as the Index of Relative Importance (Pinkas et al. 1971), $I R I=F(N+V)$, expressed as a percentage by dividing the $I R I$ of every item by the sum of the $I R I$ values for all items (Dahl \& Patterson III 2014).

We also evaluated electivity, by means of Ivlev's index (as modified by Jacobs 1974), $E=(r-p) /(r+p)$, where $r$ is the fraction (relative abundance) of an item in the stomachs and $p$ is the fraction of the same item in the environment. Environmental abundance of prey (only fish prey) was based on the data of a simultaneous study in Xcalak, with visual censuses of fish (Schmitter-Soto et al. 2017; Cobián-Rojas et al. 2018). Values of $E$ toward -1 mean avoidance or inaccessibility, whereas values approaching 1 indicate active selection, and values around zero imply random feeding.

The food items shared by the studied predators were compared by means of Kruskal-Wallis tests (Zar 1998), to detect differences ( $p<$ 0.05 ) in abundance, volume, frequency, IRI, or $E$, using the software Statistica (Statsoft 2007), A complementary, more integral approach to examine trophic overlap of the three species (pairwise) was the use of Schoener's index (Schoener 1968): $D_{j k}=1-1 / 2 \Sigma\left|p_{i j}-p_{i k}\right|$, where $p_{i j}$ and $p_{i k}$ are the fractions of each food item $i$ in the stomachs of species $j$ and $k$, respectively. Zero implies no overlap at all, and $D=1$ represents complete overlap between the species being compared; values of $D$ $>0.6$ are considered to signal substantial dietary overlap (Layman \& Allgeier 2012).

\section{Results}

We caught 60 specimens of grouper (129-270 mm LT, mean 199 $\mathrm{mm}$; 30-282 g, mean weight $136 \mathrm{~g} ; 97 \%$ juveniles), 59 of snapper (110$312 \mathrm{~mm}$ LT, mean $213 \mathrm{~mm}$; 21-520 g, mean weight $180 \mathrm{~g}$; $90 \%$ adults), and 131 of lionfish (70-380 mm LT, mean $184 \mathrm{~mm} ; 10-712 \mathrm{~g}$, mean weight $106 \mathrm{~g} ; 96 \%$ adults). According to the prey accumulation curves, our data represent about $80 \%$ of the diet composition for each species.

Empty stomachs reached $44 \%$ in lionfish, $53 \%$ in the grouper, and $68 \%$ in the snapper. For the snapper there was no clear relationship to time of day, whereas for the grouper most of the full stomachs occurred during the early morning (Figure 2).

We identified 16 taxa in stomachs of lionfish, 13 in the grouper, nine in the snapper (Table 1). All three species are predators of fish and crustaceans, although the snapper tended to prefer the latter, whereas the lionfish and the serranid were mostly piscivores (Figure 3). Because there were no environmental data available for crustaceans, electivity could be evaluated only for two species (Table 2): the grouper actively predated on Hypoplectrus sp. $(E=1)$, unlike Halichoeres sp. and Stegastes sp., whereas lionfish selected Coryphopterus glaucofraenum, C. personatus, Holacanthus ciliaris, Halichoeres maculipinna, and Cantherhines
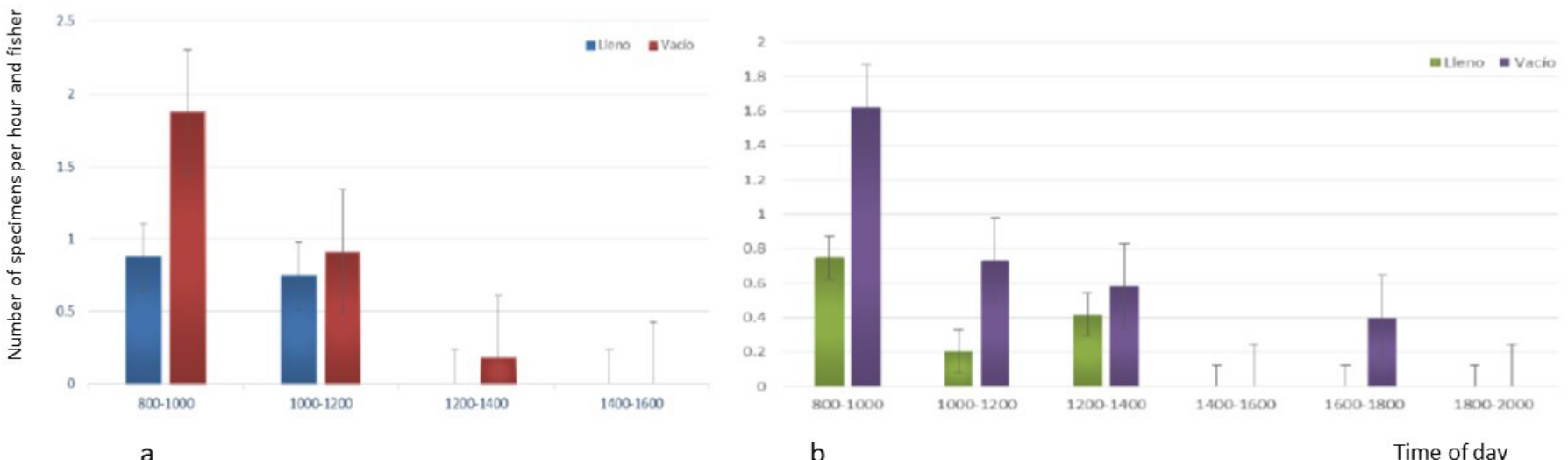

Figure 2. Specimens collected by time of day, controlled by number of hours and fishers, for (a) Cephalopholis cruentata and (b) Lutjanus apodus in Xcalak, Mexican Caribbean. Bars are standard errors. 
pullus, all with $E=1$. Some lionfish prey occurred in lower abundance in the stomachs than in the environment: Stegastes partitus, Acanthurus coeruleus, Halichoeres garnoti, and Thalassoma bifasciatum.

Table 1. Food items and their percent Index of Relative Importance in the diets of grouper Cephalopholis cruentata, snapper Lutjanus apodus, and lionfish Pterois volitans in Xcalak, Mexican Caribbean.

\begin{tabular}{|c|c|c|c|}
\hline Prey & C. cruentata & L. apodus & P. volitans \\
\hline Brachyura & 8.09 & 51.95 & 0.07 \\
\hline Fish remains & 14.89 & 8.96 & 7.46 \\
\hline Portunidae & 0.14 & 13.16 & 0 \\
\hline Coryphopterus personatus & 0 & 0 & 12.95 \\
\hline Palaemonidae & 2.50 & 1.46 & 10.88 \\
\hline $\begin{array}{l}\text { Unidentifiable organic } \\
\text { matter }\end{array}$ & 2.04 & 0.97 & 10.72 \\
\hline Hypoplectrus sp. & 1.46 & 0 & 0 \\
\hline Lyosquilla sp. & 1.40 & 0 & 0 \\
\hline Stegastes sp. & 1.09 & 0 & 0 \\
\hline Sipunculus cf. nudus & 0 & 0.88 & 0 \\
\hline Gobiidae & 0 & 0 & 0.60 \\
\hline Thalassoma bifasciatum & 0 & 0 & 0.59 \\
\hline Cronius sp. & 0 & 0.47 & 0 \\
\hline Portunus vocans & 0.34 & 0 & 0 \\
\hline Callinectes sp. & 0.15 & 0.29 & 0 \\
\hline $\begin{array}{l}\text { Coryphopterus } \\
\text { glaucofraenum }\end{array}$ & 0 & 0 & 0.28 \\
\hline Hydrozoa & 0 & 0.24 & 0 \\
\hline Stenopus sp. & 0.19 & 0 & 0 \\
\hline Panulirus sp. & 0.14 & 0 & 0 \\
\hline Halichoeres sp. & 0.12 & 0 & 0 \\
\hline Acanthurus coeruleus & 0 & 0 & 0.05 \\
\hline Balistes vetula & 0 & 0 & 0.05 \\
\hline Cantherhines pullus & 0 & 0 & 0.05 \\
\hline Halichoeres maculipinna & 0 & 0 & 0.05 \\
\hline Halichoeres garnoti & 0 & 0 & 0.03 \\
\hline Holocanthus ciliaris & 0 & 0 & 0.03 \\
\hline Stegastes partitus & 0 & 0 & 0.01 \\
\hline Pomacanthidae & 0 & 0 & 0.01 \\
\hline
\end{tabular}

The lionfish and the grouper shared as important diet items Stegastes sp., Halichoeres sp., Brachyura, and Palaemonidae. With the snapper, the lionfish shared as important prey fish remains, Brachyura, and Palaemonidae. In both cases, $D>0.6$ (0.86 and 0.99 , respectively), which implies a very high overlap in the consumption of these prey.

Most fish prey were consumed in different proportions by lionfish and snapper (usually lower consumption of fishes by the snapper), both by volume and by abundance, except for Stegastes sp. and Halichoeres sp. On the contrary, palaemonids and brachyurids were eaten in higher volume and abundance by the snapper.

\section{Discussion}

We find a substantial overlap, both in the overall diet and in particular prey items, mostly between the lionfish and the grouper, less so between lionfish and snapper. This includes also active electivity of some prey by lionfish and grouper, and foraging probably occurred at the same time of day. Trophic overlap, especially when coupled with active electivity of prey, supports the hypothesis of competition between predators (Barley et al. 2017). Competition of invasive lionfish with native predators has not been definitely proven (Côté et al. 2013); in fact, "proving" competition is controversial, because of "repeated attempts to infer causality from community patterns, without first having understood the mechanisms of the interaction" (Murray \& Illius 2000). We do not claim to "prove" competition; however, our study provides evidence of diet overlap, especially in the case of the grouper. In spite of differences in diet composition, lionfish and the grouper significantly share such prey as Halichoeres sp. and Stegastes sp., as well as brachyurans and palaemonids, which moreover are not captured opportunistically, but actively selected. Lutjanus apodus also shares with the lionfish the mentioned crustaceans, although the reliance of the snapper on them is higher.

Time of feeding directly determines percentage of empty stomachs. Both the snapper and the grouper are reported to have crepuscular habits (Randall 1967; Sierra et al. 1994), although we found more empty stomachs for the snapper during the morning, as well as an important proportion of stomachs with already digested contents, which suggests that foraging is mostly nocturnal for the snapper in Xcalak. Lionfish is also thought to hunt mostly at dawn (Green et al. 2011), although Morris \& Akins (2009) found them to be more active during the day, and García-Rivas et al. (2018) discovered that younger lionfish search for prey during the night, whereas larger individuals do so during the day. This temporal factor in habitat use contributes to minimize competition of lionfish with the snapper, but probably not with grouper.

We sampled in two seasons of the year, dry and rainy, which differ not just by the influence of rainwater on salinity close to the coast, but also because of the organic enrichment by runoff; we omitted the colder season, which in terms of precipitation is intermediate. These seasonal changes can induce shifts in dominance, especially of benthic invertebrates; Pimentel \& Joyeux (2010) did find differences in trophic niche between juvenile snappers due to this seasonal change.

One additional factor that minimizes competition between lionfish and snapper, but not between lionfish and grouper, is that the latter share fishes as preferential prey, whereas the snapper preferred crustaceans, as reported also by Muñoz et al. (2011) and Arredondo-Chávez et al. (2016). Sierra et al. (1994) observed that fish prey have a greater energy content than crustaceans. There are also differences in hunting strategy: snappers tend to hunt in group rather than individually (pers. obs., although up to one-third of lionfish hunts occur in groups, according to García-Rivas et al. 2018). These findings coincide with research in Cuba (Sierra et al. 1994) and the Bahamas (Layman \& Allgeier, 2012).

On the other hand, the diets of snappers and also of lionfish shift in varying degrees from crustaceans at young stages towards piscivory at larger sizes (McCleery 2011). This was not evident in the present study 


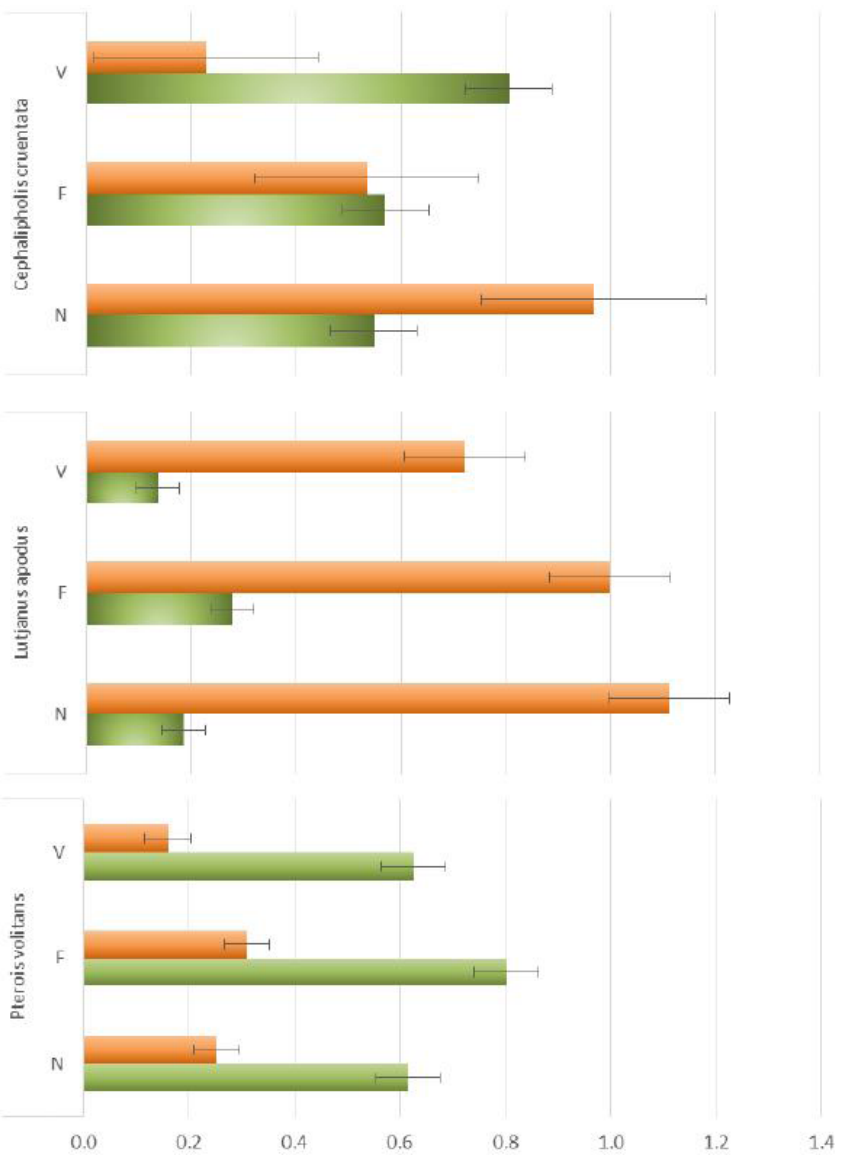

Figure 3. Importance by relative volume (V), frequency of occurrence $(\mathrm{F})$ and abundance (N) of fish (green) and crustaceans (orange) in the diet of Pterois volitans, Cephalopholis cruentata, and Lutjanus apodus in Xcalak, Mexican Caribbean. Bars are standard errors.

because of the exclusion of the smaller juveniles and the larger adults, but ontogenetic diet changes are common in fishes and are often coupled with habitat shifts, e.g. as juveniles move from mangrove to the reef as they grow (Cocheret de la Morinière et al. 2003; Nagelkerken \& van der Velde 2004). Since our study concentrated in just one habitat (the habitat where the three studied species tend to have the same sizes), the results are less confounded by ontogenetic changes, although this means also that the conclusions cannot be extrapolated to other habitats. Prey size, related to gape, can be another way to minimize competition (Barley et al. 2017), but it was uniform as well.

Predation and competition are the main ecological interactions that define community structure (Lönnstedt and McCormick, 2013). The presence of an invasive predator alters prey abundance directly, and competitor abundance indirectly, but both can be significant (Arias-González et al. 2011; Green et al. 2012; Leung et al. 2015). The impact of the invader depends on its life history, including its trophic dynamics, and also on the ecology of the invaded community (Jones \& Gomulkiewicz 2012): if the integrity of the invaded community is high (especially in terms of its species richness and the balanced presence of trophic guilds), it can be expected to display biotic resistance to invaders (Albins \& Hixon 2011). In particular, it has been suggested that large groupers and sharks could exert some biological control on lionfish (Mumby et al. 2011). However, in the western Caribbean, this has been shown not to be the case in the Bahamas (Anton et al. 2014), Mexico and Cuba (Cobián-Rojas, Schmitter-Soto, Aguilar Betancourt et al. 2018), and also Belize (Hackerott et al. 2013).

The conclusion of Valdivia et al. (2014) is that managers should not rely on native predators to outcompete lionfish, and, same as CobiánRojas, Schmitter-Soto, Aguilar Betancourt, et al.(2018), that the biotic resistance hypothesis is most often not supported. Hackerott et al. (2013) found that the density of lionfish had no relationship to the density of native predators. This implies a gloomy outlook for local faunas; generalist predators tend to be more successful as invaders (Muñoz et al. 2011), especially when their strategies are unknown to native prey (Layman \& Allgeier, 2012). Because of the similarity in hunting habits, rather than competing with snappers and groupers, the lionfish could be anticipated to compete with the native Caribbean scorpaenid of comparable size, Scorpaena plumieri. Arredondo-Chávez et al. (2016)

Table 2. Relative abundance of prey of lionfish Pterois volitans and grouper Cephalopholis cruentata in Xcalak, Mexican Caribbean, in two natural habitats and in the stomachs. Ivlev's electivity index (E) also shown. Full names of species, in Table 1.

\begin{tabular}{|c|c|c|c|c|c|}
\hline Prey & Reef lagoon & Frontal reef & P. volitans & C. cruentata & $E$ \\
\hline A. coeruleus & 2.5 & 2.0 & 1.0 & - & -0.3 \\
\hline B. vetula & 0 & 1.0 & 1.0 & - & 0 \\
\hline C. glaucofraenum & 0 & 0 & 1.0 & - & 1.0 \\
\hline C. personatus & 0 & 0 & 2.9 & - & 1.0 \\
\hline H. maculipinna & 0 & 0 & 1.0 & - & 1.0 \\
\hline Halichoeres sp. & 2.2 & 0 & - & 1.0 & -0.4 \\
\hline H. ciliaris & 1.0 & 0 & 1.0 & - & 1.0 \\
\hline Hypoplectrus sp. & 0 & 0 & - & 1.0 & 1.0 \\
\hline S. partitus & 1.8 & 3.2 & 1.0 & - & -0.5 \\
\hline
\end{tabular}


found that $S$. plumieri preferred octopi, which are rare or absent from lionfish diet; however, based on analyses of stable isotopes of nitrogen and carbon, the same author proved niche overlap not just between both scorpaenids, but also among both the grouper and the snapper.

Raymond et al. (2015) found that prey tend to be captured preferably by the largest predator. Although the size intervals overlapped completely in our samplings, lionfish was largest (380 mm TL), followed by the snapper $(310 \mathrm{~mm})$ and the grouper $(199 \mathrm{~mm})$. Pterois volitans can reach $490 \mathrm{~mm}$ in invaded habitats (Darling et al. 2011). This is an additional advantage for the invader in Xcalak and many other Caribbean localities, where larger snappers and groupers, as well as sharks, have become very scarce, due mainly to historical overfishing in addition to coastal development and other impacts on the coral reef (Schmitter-Soto et al. 2017).

Our prey accumulation model fell short of the results of ArredondoChávez et al. (2016), who found 79 prey items in lionfish stomachs, quite above the prediction of our model, and also much more than what was reported by Muñoz et al. (2011), who listed only 18 prey items, or even Valdez-Moreno et al. (2012), with 34 species, most of these identified using molecular markers. We think that the difference is due not to sample size (number of stomachs), but rather to geographic diversity: Arredondo-Chávez et al. (2016) worked in six localities spread over the Caribbean coast of Mexico, two of them insular. It is known that lionfish diet varies opportunistically by region and habitat (Pimiento et al. 2013; García-Rivas et al. 2017).

According to Lönnstedt and McCormick (2013), invasive predators with generalist feeding habits are expected to have more severe effects on the invaded community, because of the multiple and often more complex roles that they can play. The wide trophic niche of the lionfish has been confirmed by many authors (McCleery 2011; Muñoz et al. 2011; Ruttenberg et al. 2012; Valdez-Moreno et al. 2012). Notwithstanding, even generalist or opportunistic predators can display some active prey selection. The preference for a given food item can be due to its being more profitable in energetic terms (Begon et al. 1987), or else a methodological artifact, especially in the case of cryptic prey, such as gobies, underestimated in visual censuses (Green et al. 2012). Other important food items for lionfish and its putative competitors at Xcalak, prey such as $S$. partitus, $A$. coeruleus, $H$. garnoti, and $T$. bifasciatum, are among the most abundant fish species in the environment (SchmitterSoto et al. 2017), and yet they had a negative electivity index, which does not support the idea of opportunistic predation.

Prey naïveté has been invoked as an explanation for the competitive advantage of invasive predators: the grouper or the snapper may be recognized as potential predators, whereas lionfish is not, because it has not coevolved with the local ichthyofauna (Côté et al. 2013; Leung et al. 2015). Nevertheless, it is remarkable that local fish species have quite quickly "learned" to "use" the presence of lionfish to their benefit, in spite of facing a new predator: such potential prey as the fairy basslet (Gramma loreto) have been found to share refugia with lionfish at night, presumably seeking protection from nocturnal marauders (García-Rivas et al. 2017).

Dahl \& Patterson (2014) predicted that the negative impacts of lionfish will surely increase as their populations grow. In addition, the historic or continuing overfishing of native piscivores, such as Epinephelus guttatus, E. striatus, C. cruentata, C. fulva, L. apodus,
L. griseus, and L. jocu, has affected their abundance in Xcalak and generally in the western Caribbean in the last decades (Schmitter-Soto et al. 2017). Moreover, lionfish preys on fish from different trophic guilds (herbivores, detritivores, small predators), as well as diverse macroinvertebrates. Therefore, its impact extends across trophic levels (Lönnstedt \& McCormick 2013).

In conclusion, the trophic overlap between the lionfish and the two putative competitors, especially the grouper, was high, including prey that were selected by the predators, and probably at the same time of day, so the hypothesis of competition between them for particular prey is supported. Although the expansion of invasive lionfish in the Caribbean is likely reaching a limit in distribution, abundance, and body size (Cobián-Rojas et al. 2016; Sabido-Itzá et al. 2016), and albeit the diet overlap here shown does not necessarily imply a "domino effect" across the trophic web, as modelled by Arias-González et al. (2011), we think it is most prudent to continue the culling programs of lionfish (Côté et al. 2014), and also to monitor the abundance of possible competitors, such as snapper and grouper, in such long-term endeavors as the Atlantic and Gulf Rapid Reef Assessment Program, AGRRA (Ginsburg \& Lang 2003).

\section{Acknowledgements}

Fish captures were carried out under fishing permit No. PPF/ DGOPA-053-15 by the Mexican National Fishery Commission (CONAPESCA) and authorization to work within the national marine park at Xcalak by the Mexican National Commission of Protected Areas (CONANP), for which we are grateful, especially to directors Maricarmen García-Rivas and Jorge M. Gómez-Poot. This article is part of the graduate thesis of the first author, who thanks Xavier Chiappa-Carrara and Héctor Espinosa Pérez for guidance during the dissertation, and the Mexican National Council of Science and Technology (CONACYT) for a grant. José Ángel Cohuó, Susana Perera, Héctor Salvat, Yasuri Velázquez, and many fishers at Xcalak helped in the field. Gabriel Cruz provided the map.

\section{Author Contributions}

Brenda Iveth Murillo-Pérez: Substantial contribution in the concept and design of the study and contribution to data collection, as well as contribution to data analysis and interpretation and to manuscript preparation.

Juan Jacobo Schmitter-Soto: Substantial contribution in the concept and design of the study and contribution to data collection, as well as contribution to data analysis and interpretation and to manuscript preparation.

Dorka Cobián-Rojas: Contribution to data collection and adding intellectual content.

Roberto Luis Herrera-Pavón: Contribution to data collection and adding intellectual content.

\section{Conflicts of Interest}

The authors declare that they have no conflict of interest related to the publication of this manuscript. 


\section{Ethics}

The paper does not involve human beings or clinical trials.

\section{Data availability}

The authors are willing to share their data in a public repository, although the data are already available to the public as part of the dissertation by the first author at the Universidad Nacional Autónoma de México.

\section{References}

ALBINS, M.A. 2013. Effects of invasive Pacific red lionfish Pterois volitans versus a native predator on Bahamian coral-reef fish communities. Biol. Invasions 15(1):29-43.

ALBINS, M.A. \& HIXON, M.A. 2011. Worst case scenario: potential long-term effects of invasive predatory lionfish (Pterois volitans) on Atlantic and Caribbean coral-reef communities. Environ. Biol. Fishes 96:1151-1157.

ANTON, A., SIMPSON, M.S. \& VU, I. 2014. Environmental and biotic correlates to lionfish invasion success in Bahamian coral reefs. PLoS One 9(9):e106229.

ARIAS-GONZÁLEZ, J.E., GONZÁLEZ-GÁNDARA, C., CABRERA, J.L. \& CHRISTENSEN, V. 2011. Predicted impact of the invasive lionfish Pterois volitans on the food web of a Caribbean coral reef. Environ. Res. 111:917-925.

ARREDONDO-CHÁVEZ, A.T., SÁNCHEZ-JIMÉNEZ, J.A., ÁVILAMORALES, Ó.G., TORRES-CHÁVEZ, P., HERRERIAS-DIEGO, Y., MEDINA-NAVA, M., MADRIGAL-GURIDI, X., CAMPOS-MENDOZA, A., DOMÍNGUEZ-DOMÍNGUEZ, O. \& CABALLERO-VÁZQUEZ, J.A. 2016. Spatio-temporal variation in the diet composition of red lionfish, Pterois volitans (Actinopterygii: Scorpaeniformes: Scorpaenidae), in the Mexican Caribbean: insights into the ecological effect of the alien invasion. Acta Ichthyol. Piscat. 46(3):182-200.

BARLEY, S.C., MEEKAN, M.G. \& MEEUWIG, J.J. 2017. Species diversity, abundance, biomass, size and trophic structure of fish assemblages on coral reefs in relation to shark abundance. Mar. Ecol. Prog. Ser. 565163-179.

BEGON, M., HARPER, J.L. \& TOWNSEND, C.R. 1987. Ecología: individuos, poblaciones y comunidades. 2nd ed. Omega, Mexico City.

COBIÁN-ROJAS, D., CHEVALIER MONTEAGUDO, P.P., SCHMITTERSOTO, J.J., CORRADA WONG, R.I., SALVAT TORRES, H., CABRERA SANSÓN, E., GARCÍA RODRÍGUEZ, A., FERNÁNDEZ OSORIO, A., ESPINOSA PANTOJA, L., CABRERA GUERRA, D., PANTOJA ECHEVARIA, L.M., CABALLERO-ARAGÓN, H. \& PERERA VALDERRAMA, S. 2016. Density, size, biomass, and diet of lionfish in Guanahacabibes National Park, western Cuba. Aquat. Biol. 24(3):219-226.

COBIÁN-ROJAS, D., SCHMITTER-SOTO, J.J., AGUILAR-PERERA, A., AGUILAR BETANCOURT, C.M., RUIZ-ZÁRATE, M.Á., GONZÁLEZSANSÓN, G., CHEVALIER MONTEAGUDO, P.P., GARCÍA RODRÍGUEZ, A., HERRERA-PAVÓN, R.L., PERERA VALDERRAMA S., CABALLERO ARAGÓN, H. \& DE LA GUARDIA LLANSÓ, E. 2018. Diversidad de las comunidades de peces en dos áreas marinas protegidas del Caribe y su relación con el pez león. Rev. Biol. Trop. 66(1):189-203.

COBIÁN-ROJAS, D., SCHMITTER-SOTO, J.J., AGUILAR BETANCOURT, C.M., AGUILAR-PERERA, A., RUIZ-ZÁRATE, M.Á., GONZÁLEZSANSÓN, G., CHEVALIER MONTEAGUDO, P.P., HERRERA-PAVÓN, R.L., GARCÍA RODRÍGUEZ, A., CORRADA WONG, R.I., CABRERA GUERRA, D., SALVAT TORRES, H. \& PERERA VALDERRAMA, S. 2018. The community diversity of two Caribbean MPAs invaded by lionfish does not support the biotic resistance hypothesis. J. Sea Res. 13426-33.

COCHERET DE LA MORINIÈRE, E., POLLUX, B.J.A., NAGELKERKEN, I., HEMMINGA, M.A., HUISKES, A.H.L. \& VAN DER VELDE, G. 2003. Ontogenetic dietary changes of coral reef fishes in the mangrove-seagrassreef continuum: stable isotopes and gut-content analysis. Mar. Ecol. Prog. Ser. 246279-289.
CORTÉS, E. 1997. A critical review of methods of studying fish feeding based on analysis of stomach contents: application to elasmobranch fishes. Can. J. Fish. Aquat. Sci. 54(3):726-738.

CÔTÉ, I.M., AKINS, J.L., UNDERWOOD, E., CURTIS-QUICK, J. \& GREEN, S.J. 2014. Lionfish control: culling works. PeerJ (2):e398v1.

CÔTÉ, I.M., GREEN, S.J. \& HIXON, M.A. 2013. Predatory fish invaders: insights from Indo-Pacific lionfish in the western Atlantic and Caribbean Biol. Conserv. 16450-61.

DAHL, K.A. \& PATTERSON III, W.F. 2014. Habitat-specific density and diet of rapidly expanding invasive red lionfish, Pterois volitans, populations in the northern Gulf of Mexico. PLoS One 9(8):e105852.

DARLING, E.S., GREEN, S.J., O’LEARY, J.K. \& CÔTÉ, I.M. 2011. Indo-Pacific lionfish are larger and more abundant on invaded reefs: a comparison of Kenyan and Bahamian lionfish populations. Biol. Invasions 13(9):2045-2051.

ESPINOZA-ÁVALOS, J., ISLEBE, G.A. \& HERNÁNDEZ-ARANA, H.A. 2009. El Sistema Ecológico de la Bahía de Chetumal/Corozal: Costa Occidental del Mar Caribe. El Colegio de la Frontera Sur, Chetumal, Mexico.

FERREIRA, C.E.L., LUIZ, O.J., FLOETER, S.R., LUCENA, M.B., BARBOSA, M.C., ROCHA, C.R. \& ROCHA, L.A. 2015. First record of invasive lionfish (Pterois volitans) for the Brazilian coast. PLoS One 10(4):e123002.

FROESE, R. \& PAULY, D.A. 2020. FishBase. World Wide Web Electron. Publ.

GARCÍA-RIVAS, M. del C., MACHKOUR M'RABET, S.C., PÉREZLACHAUD, G., SCHMITTER-SOTO, J.J., CÉRÉGHINO, R., DONEYS, C., ST-JEAN, N. \& HÉNAUT, Y. 2018. Age-dependent strategies related to lionfish activities in the Mexican Caribbean. Environ. Biol. Fishes 101(4):563-578.

GARCÍA-RIVAS, M. del C., MACHKOUR M'RABET, S.C., PÉREZLACHAUD, G., SCHMITTER-SOTO, J.J., DONEYS, C., ST-JEAN, N., COBIÁN-ROJAS, D. \& HÉNAUT, Y. 2017. What are the characteristics of lionfish and other fishes that influence their association in diurnal refuges? Mar. Biol. Res. 13(8):899-908.

GINSBURG, R.N. \& LANG, J.C. 2003. Status of coral reefs in the western Atlantic: results of initial surveys, Atlantic and Gulf Rapid Reef Assessment (AGRRA) program. Atoll Res. Bull. 496.

GREEN, S.J., AKINS, J.L. \& CÔTÉ, I.M. 2011. Foraging behaviour and prey consumption in the Indo-Pacific lionfish on Bahamian coral reefs. Mar. Ecol. Prog. Ser. 433159-167.

GREEN, S.J., AKINS, J.L., MALJKOVIĆ, A. \& CÔTÉ, I.M. 2012. Invasive lionfish drive Atlantic coral reef fish declines. PLoS One 7(3):e32596.

GUZMÁN-MÉNDEZ, I.A., RIVERA-MADRID, R., DÍAZ-JAIMES, P. \& GARCÍA-RIVAS, M. del C. 2017. First genetically confirmed record of the invasive devil firefish Pterois miles (Bennett, 1828) in the Mexican Caribbean. Biodivers. Conserv. 699-103.

HACKEROTT, S., VALDIVIA, A., GREEN, S.J., CÔTÉ, I.M., COX, C.E., AKINS, J.L., LAYMAN, C.A., PRECHT, W.F. \& BRUNO, J.F. 2013. Native predators do not influence invasion success of Pacific Lionfish on Caribbean reefs. PLoS One 8(7):e68259.

HERNÁNDEZ-ARANA, H.A., ESPINOZA-ÁVALOS, J., CARRILLO, L., WEISSENBERGER, H. \& GARCÍA-RIVAS, M. del C. 2009. Caracterización del área natural protegida Parque Nacional Arrecifes de Xcalak y formulación de un programa de monitoreo. Final report to CONABIO, Mexico City.

JACOBS, J. 1974. Quantitative measurement of food selection. Oecologia 14:413-417.

JIMÉNEZ-VALVERDE, A. \& HORTAL, J. 2003. Las curvas de acumulación de especies y la necesidad de evaluar la calidad de los inventarios biológicos. Rev. Ibérica Aracnol. 8151-161.

JONES, E.I. \& GOMULKIEWICZ, R. 2012. Biotic interactions, rapid evolution, and the establishment of introduced species. Am. Nat. 179(2):28-36.

JORDÁN-DAHLGREN, E. \& RODRÍGUEZ-MARTÍNEZ, R.E. 1998. Posthurricane initial recovery of Acropora palmata in two reefs of the Yucatán Peninsula, Mexico. Bull. Mar. Sci. 63(1):213-228. 
JUD, Z.R., NICHOLS, P.K. \& LAYMAN, C.A. 2014. Broad salinity tolerance in the invasive lionfish Pterois spp. may facilitate estuarine colonization. Environ. Biol. Fishes 98(1):135-143.

LAYMAN, C.A. \& ALLGEIER, J.E. 2012. Characterizing trophic ecology of generalist consumers: a case study of the invasive lionfish in the Bahamas. Mar. Ecol. Prog. Ser. 448131-141.

LEUNG, M.-R., PADILLA, D., SONG, B., KANG, Y., SHEMER, N. \& VINAGERA, J. 2015. A symmetric intraguild predation model for the invasive lionfish and native grouper. Commun. Math. Biol. Neurosci. 5(4):1-18.

LÖNNSTEDT, O.M. \& MCCORMICK, M.I. 2013. Ultimate predators: lionfish have evolved to circumvent prey risk assessment abilities. PLoS One 8(10): 75781

LORETO-VIRUEL, R.M., LARA, M. \& SCHMITTER-SOTO, J.J. 2003. Coral reef fish assemblages at Banco Chinchorro, Mexican Caribbean. Bull. Mar. Sci. 73(1):153-170

MCCLEERY, C. 2011. A comparative study of the feeding of invasive lionfish (Pterois volitans) in the Caribbean. Physis J. Mar. Sci. 938-43.

MILLS, M.D., RADER, R.B. \& BELK, M.C. 2004. Complex interactions between native and invasive fish: the simultaneous effects of multiple negative interactions. Oecologia 141(4):713-721.

MORRIS, J.A. \& AKINS, J.L. 2009. Feeding ecology of invasive lionfish (Pterois volitans) in the Bahamian archipelago. Environ. Biol. Fishes 86389-398.

MUMBY, P.J., HARBORNE, A.R. \& BRUMBAUGH, D.R. 2011. Grouper as a natural biocontrol of invasive lionfish. PLoS One 6(6):e21510.

MUÑOZ, R.C., CURRIN, C.A. \& WHITFIELD, P.E. 2011. Diet of invasive lionfish on hard bottom reefs of the southeast USA: insights from stomach contents and stable isotopes. Mar. Ecol. Prog. Ser. 432181-193.

MURRAY, M.G. \& ILLIUS, A.W. 2000. Vegetation modification and resource competition in grazing ungulates. Oikos 89(3):501-508.

NAGELKERKEN, I. 2007. Are non-estuarine mangroves connected to coral reefs through fish migration? Bull. Mar. Sci. 80(3):595-607.

NAGELKERKEN, I. \& VAN DER VELDE, G. 2004. Relative importance of interlinked mangroves and seagrass beds as feeding habitats for juvenile reef fish on a Caribbean island. Mar. Ecol. Prog. Ser. 274153-159.

PAOLUCCI, E.M., MACISAAC, H.J. \& RICCIARDI, A. 2013. Origin matters: alien consumers inflict greater damage on prey populations than do native consumers. Divers. Distrib. 19(8):988-995.

PIMENTEL, C.R. \& JOYEUX, J.-C. 2010. Diet and food partitioning between juveniles of mutton Lutjanus analis, dog Lutjanus jocu and lane Lutjanus synagris snappers (Perciformes: Lutjanidae) in a mangrove-fringed estuarine environment. J. Fish Biol. 76(10):2299-2317.

PIMIENTO, C., NIFONG, J.C., HUNTER, M.E., MONACO, M.E. \& SILLIMAN, B.R. 2013. Habitat use patterns of the invasive red lionfish Pterois volitans: a comparison between mangrove and reef systems in San Salvador, Bahamas. Mar. Ecol. 36(1):28-37.

PINKAS, L., OLIPHANT, M.S. \& IVERSON, I.L.K. 1971. Food habits of Albacore, Bluefin Tuna, and Bonito in California waters. Fish. Bull. $1525-10$.

RANDALL, J.E. 1967. Food habits of reef fishes of the West Indies. Stud. Trop. Oceanogr. 5665-847.
RAYMOND, W.W., ALBINS, M.A. \& PUSACK, T.J. 2015. Competitive interactions for shelter between invasive Pacific red lionfish and native Nassau grouper. Environ. Biol. Fishes 98(1):57-65.

RUIZ-ZÁRATE, M.Á., HERNÁNDEZ-LANDA, R.C., GONZÁLEZ-SALAS, C., NÚÑEZ-LARA, E. \& ARIAS-GONZÁLEZ, J.E. 2003. Condition of coral reef ecosystems in central-southern Quintana Roo, Mexico (part 1: stony corals and algae). Atoll Res. Bull. 496318-337.

RUTTENBERG, B.I., SCHOFIELD, P.J., AKINS, J.L., ACOSTA, A.M., FEELWY, M.W., BLONDEAU, J., SMITH, S.G. \& AULT, J.S. 2012. Rapid invasion of Indo-Pacific lionfishes (Pterois volitans and Pterois miles) in the Florida Keys, USA: evidence from multiple pre-and post-invasion data sets. Bull. Mar. Sci. 88(4):1051-1059.

SABIDO-ITZÁ, M.M., MEDINA-QUEJ, A., DE JESÚS-NAVARRETE, A., GÓMEZ-POOT, J.M. \& GARCÍA-RIVAS, M. del C. 2016. La estructura de tallas como evidencia del establecimiento de Pterois volitans (Scorpaeniformes: Scorpaenidae) en el sur del Caribe mexicano. Rev. Biol. Trop. 64(1):353-362.

SCHMITTER-SOTO, J.J., AGUILAR-PERERA, A., CRUZ-MARTÍNEZ, A., HERRERA-PAVÓN, R.L., MORALES-ARANDA, A.A. \& COBIÁNROJAS, D. 2017. Interdecadal trends in composition, density, size, and mean trophic level of fish species and guilds before and after coastal development in the Mexican Caribbean. Biodivers. Conserv. 27(2):459-474.

SCHOENER, T.W. 1968. The Anolis lizards of Bimini: resource partitioning in a complex fauna. Ecology 49(4):704-726.

SEMMENS, B.X., BUHLE, E.R., SALOMON, A.K. \& PATTENGILLSEMMENS, C. V. 2004. A hotspot of non-native marine fishes: evidence for the aquarium trade as an invasion pathway. Mar. Ecol. Prog. Ser. 266239-244.

SIERRA, L.M., CLARO, R. \& POPOVA, O.A. 1994. Alimentación y relaciones tróficas. In Ecología de los peces marinos de Cuba (R. Claro, ed.) Instituto de Oceanología / Centro de Investigaciones de Quintana Roo, Chetumal, p.263-320.

STATSOFT. 2007. Statistica. version 8.0. StatSoft Inc.

VALDEZ-MORENO, M.E., QUINTAL-LIZAMA, C., GÓMEZ-LOZANO, R. \& GARCÍA-RIVAS, M. del C. 2012. Monitoring an alien invasion: DNA barcoding and the identification of lionfish and their prey on coral reefs of the Mexican Caribbean. PLoS One 7(6):1-8.

VALDIVIA, A., BRUNO, J.F., COX, C.E., HACKEROTT, S. \& GREEN, S.J. 2014. Re-examining the relationship between invasive lionfish and native grouper in the Caribbean. PeerJ 2e348.

WEIS, J.S. 2011. Invasion and predation in aquatic ecosystems. Curr. Zool. 57(5):613-624.

WHITE, E.M., WILSON, J.C. \& CLARKE, A.R. 2006. Biotic indirect effects: a neglected concept in invasion biology. Divers. Distrib. 12443-455.

ZAR, J.H. 1998. Biostatistical Analysis. 4th ed. Prentice Hall, New Jersey.

Received: 21/10/2019

Revised: 05/06/2020

Accepted: 05/11/2020

Published online: 02/04/2021 